\title{
Influence of plant residual compost and ash on yield and economic performance of cherry tomato
}

\author{
M. N. Mondol*, A. S. Chamon and M. M. Rahman
}

Department of Soil, Water and Environment, University of Dhaka, Dhaka-1000, Bangladesh

\begin{abstract}
A field experiment was conducted with different levels of compost, ash and their mixture to investigate the effect of compost and ash on their vegetative growth, fruiting characteristics as well as yield attributes and economic performance of cherry tomato (Solanum lycopersicum var. cerasiforme). The plots were treated with three levels of compost/ash (5.10 and $15 \mathrm{t} / \mathrm{ha})$ and three levels of compost+ash mixture i.e. $(2.5+2.5),(5.5+5.5)$ and $(7.5+7.5) \mathrm{t} / \mathrm{ha}$. There were three replication for each treatment. The highest plant height, number of cluster/plant, number of flower/plant, fruit yield/plant, fruit yield/ha were obtained from the treatment T10 receiving $7.5 \mathrm{t}$ compost $+7.5 \mathrm{t}$ ash/ha. Compost significantly increased fresh matter production of tomato fruit yield compared to the control. Between compost and ash, performance of compost was better. It was further observed that the combination of $7.5 \mathrm{t}$ compost $+7.5 \mathrm{t}$ ash/ha appeared to be the economically viable treatment which offered maximum benefit cost ratio (3.25) for cherry tomato production.
\end{abstract}

Keywords: Cherry tomato; Yield; Economic performance.

\section{Introduction}

A cherry tomato is a small variety of tomato that has been cultivated since at least the early 1800 s and thought to have originated in Peru and Northern Chile (Andrew, 1994). Cherry tomatoes range in size from a thumb tip up to the size of a golf ball, and can range from being spherical to slightly oblong in shape. The cherry tomato is regarded as a botanical variety of the cultivated berry, Solanum lycopersicum var. cerasiforme. Cherry tomatoes have been popular in the United States since at least 1919 (Andrew, 1994). It is a very popular vegetable, are a smaller variety of the common garden tomato that is generally sweeter than larger fruits. Tomatoes are eaten raw or cooked, but the smaller cherry tomatoes are more often eaten raw just because of their size. Pearly round or plum-shaped, tangy or sweet, red or gold, cherry tomatoes top off summer salads, sweeten party trays, and treat the kids. They are high in vitamins $\mathrm{A}$ and $\mathrm{C}$, and are great sources for potassium, vitamin $\mathrm{K}$ and even fiber.

The majority of tomato growers in Bangladesh do not get good quality fruit and high yield because of their ignorance about improved production technology including use of proper organic and inorganic nutrients. Soil and fertilizer management in the traditional way caused yield decline in the Philippines (Cassman et al., 1995) and in India (Singh and Dixit, 1995). Soil organic matter (SOM) content strongly influences soil fertility by means of its influence on nutrient cycling and on the physical, chemical and biological properties of soils (Stevenson, 1994). The addition of organic residual compost is added to increase the soil organic carbon content (Giardini et al., 1999).

In agriculture, plant material residue has been used to improve soil fertility for thousands of years. Besides nutrient recycling such as nitrogen $(\mathrm{N})$, phosphorus $(\mathrm{P})$ and potassium $(\mathrm{K})$, plant residues may significantly increase soil $\mathrm{pH}$ (Pocknee and Sumner, 1997). This property of plant residue is especially important in the management of acidic soils, such as in tropic and other high rainfall environments, where soil $\mathrm{pH}$ and aluminium (Al) concentrations are critical factors for plant growth and where it is impractical to use mineral lime because of lack of availability or excessive cost (Hue, 1992). The liming effect of plant materials has been found to be closely related to their total concentration of calcium $(\mathrm{Ca})$, magnesium $(\mathrm{Mg})$, and potassium $(\mathrm{K})$ (Pocknee and Sumner, 1997).

A very important factor is normally considered in improving crop productivity is the soil organic matter. In Bangladesh, low and declining organic matter due to reduced recycling of organic residues is affecting soil fertility and productivity 
(Saheed, 1992). Most soils of Bangladesh have less than $1.5 \%$, some soils have less than $1 \%$ organic matter (BARC, 1997). Because of the tropical climate, organic matter decomposition in soils of Bangladesh is high. The addition of organic materials to soil through farmyard manure, composts and plant/organic residues has been reduced considerably because a major portion of these organic is used up as fuel by the rural population. Moreover, the organic matter content of our soil is declining with time due to less attention to its improvement and maintenance (Karim et al., 1994). Addition of manure, compost increased total organic matter, macronutrients $(\mathrm{N}, \mathrm{P}, \mathrm{Mg}, \mathrm{Na}, \mathrm{Ca}$ and $\mathrm{K}$ ) and micronutrients $(\mathrm{Cu}, \mathrm{Zn}$ and $\mathrm{Mn})$ in the amended soils according to the rate of compost application (Wong et al., 1999).

Keeping these facts in mind the present study was undertaken to evaluate the effects of garden plant residual compost and ash in different rates to micro-plot agricultural plot on the crop productivity and profitability of cherry tomato.

\section{Materials and methods}

A micro-plot field experiment was carried out at the Department of Soil, Water and Environment, University of Dhaka, Bangladesh. The soil had the following general characteristics; sand- $60 \%$, silt-30\%, clay- $10 \%$, pH- 6.6, organic matter $0.81 \%$, available N \& P were 116.66 \& 10.56 ppm, exchangeable $\mathrm{K}, \mathrm{Na}, \mathrm{Ca} \& \mathrm{Mg}$ were $0.11,1.22,1.09 \& 1.89$ meq/100 gm soil. Total $\mathrm{Fe}, \mathrm{Cu}, \mathrm{Mn}$, and $\mathrm{Zn}$ in soil were $0.0019 \%, 81.3 \mathrm{mg} / \mathrm{kg}, 344 \mathrm{mg} / \mathrm{kg}$ and $278 \mathrm{mg} / \mathrm{kg}$.

The compost had the following general characteristics; total organic carbon $7.44 \%$, total organic matter $12.80 \%$, total $\mathrm{N}$, $\mathrm{P}, \mathrm{K}, \mathrm{Ca}, \mathrm{Fe}, \mathrm{Mg}, \mathrm{Cu}, \mathrm{Mn}$ and $\mathrm{Zn}$ were $1.55 \%, 0.088 \%$, $0.29 \%, 0.016 \%, 0.01 \%, 1.09 \%, 189 \mathrm{mg} / \mathrm{kg}, 548 \mathrm{mg} / \mathrm{kg}$ and $455 \mathrm{mg} / \mathrm{kg}$.

The ash had the following general characteristics; total organic carbon $1.65 \%$, total organic matter $2.83 \%$, total $\mathrm{N}, \mathrm{P}$, $\mathrm{K}, \mathrm{Ca}, \mathrm{Mg}, \mathrm{Cu}, \mathrm{Mn}$ and $\mathrm{Zn}$ were $0.58 \%, 0.045 \%, 0.49 \%$, $0.012 \%, 0.023 \%, 119 \mathrm{mg} / \mathrm{kg}, 311 \mathrm{mg} / \mathrm{kg}$ and $375 \mathrm{mg} / \mathrm{kg}$.

There were 10 treatments consisting of 3 rates of compost $(5$, $10 \& 15 \mathrm{t} / \mathrm{ha}), 3$ rates of ash $(5,10 \& 15 \mathrm{t} / \mathrm{ha}), 3$ rates of compost-ash mixture $(2.5+2.5,5+5, \& 7.5+7.5 \mathrm{t} / \mathrm{ha})$ and 1 control (T1) (no compost or ash).

The experiment was laid out in a completely randomized design with three replications of each treatment. Each plot (1 $\mathrm{m}^{2}$ ) received $80 \mathrm{~kg} \mathrm{~N} / \mathrm{ha}, 50 \mathrm{~kg}_{2} \mathrm{O}_{5} /$ ha and $40 \mathrm{~kg} \mathrm{~K} 2 \mathrm{O} / \mathrm{ha}$ from urea, TSP and MP, respectively. Tomatos (5 plants/plot, one month old seedling) were planted in each plot. The treatments were applied before two weeks of plantation. Intercultural operations were done as and when necessary. After 11 weeks of plantation, crops were harvested. Data on plant height, dry weight of shoot, number of clusters per plant, number of flower per plant, number of fruits per plant, fruit setting rate $(\%)$ and fruit yield per plant were recorded from each plot. Tomato fruits were separated and fresh weights per plant/plot were recorded. Total yield/ha was calculated from the yield recorded in each plot. Fruit setting rate (FSR) was calculated as:

FSR $(\%)=\frac{\text { Total number of fruits per plant }}{\text { Total number of flower per plant }} \times 100$

The benefit cost ratio (BCR) was calculated as:

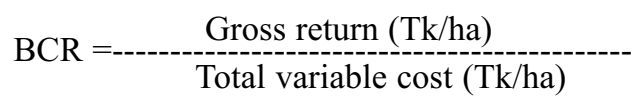

The cost of labour, land preparation, seedling transplanting, compost and urea fertilizer were considered as the total variable cost of the experiment and fruit yield/ha was considered as experimental produce. The collected data were analyzed statistically. Means were separated using DMRT.

\section{Results and discussion}

Growth and yield parameters

\section{Plant height}

Application of organic manure resulted in significant differences in biomass production. Shoot and root length of tomato which is an important parameter affecting the growth significantly varied due to different Treatments (Table I). The highest shoot length of $69.00 \mathrm{~cm}$ was observed in the treatment T10 receiving $7.5 \mathrm{t} / \mathrm{ha}$ compost $+7.5 \mathrm{t} / \mathrm{ha}$ ash. All the treatments recorded statistically higher shoot length over control except treatment T2 and T5. Root length ranged from $20 \mathrm{~cm}$ in control to $34 \mathrm{~cm}$ recorded in the treatment $\mathrm{T} 10$. Solaiman and Rabbani (2007) reported that plots incorporated with $15 \mathrm{t}$ compost $+100 \mathrm{~kg} \mathrm{~N} /$ ha produced highest plant height than plots without compost. 
Table I. Fresh and dry weight of cherry tomato (g/plant) as influenced by different levels of plant residual compost and ash

\begin{tabular}{lccccc}
\hline Treatment & $\begin{array}{c}\text { Shoot length } \\
(\mathrm{cm})\end{array}$ & $\begin{array}{c}\text { Root length } \\
(\mathrm{cm})\end{array}$ & $\begin{array}{c}\text { DW } \\
(\mathrm{g})\end{array}$ & $\begin{array}{c}\text { shoot/plant } \\
(\mathrm{g})\end{array}$ & $\begin{array}{c}\text { DW root/plant } \mathrm{F} \text { W fruit/plant } \\
(\mathrm{g})\end{array}$ \\
\hline T1-control & $49 \mathrm{hi}$ & $20 \mathrm{a}$ & $13.56 \mathrm{a}$ & $1.93 \mathrm{a}$ & $104.8 \mathrm{a}$ \\
T2-5 t/ha compost & $50 \mathrm{gh}$ & $26 \mathrm{c}$ & $15.77 \mathrm{~b}$ & $2.28 \mathrm{c}$ & $160.0 \mathrm{~d}$ \\
T3-10 t/ha compost & $52 \mathrm{f}$ & $28 \mathrm{~d}$ & $18.09 \mathrm{c}$ & $3.23 \mathrm{f}$ & $172.0 \mathrm{e}$ \\
T4- 15 t/ha compost & $61 \mathrm{~b}$ & $29 \mathrm{e}$ & $21.08 \mathrm{~d}$ & $3.91 \mathrm{~h}$ & $188.0 \mathrm{f}$ \\
T5-5 t/ha ash & $48 \mathrm{i}$ & $21 \mathrm{a}$ & $14.02 \mathrm{a}$ & $2.21 \mathrm{~b}$ & $105.8 \mathrm{a}$ \\
T6-10 t/ha ash & $51 \mathrm{fg}$ & $23 \mathrm{~b}$ & $17.77 \mathrm{c}$ & $2.30 \mathrm{~d}$ & $108.7 \mathrm{~b}$ \\
T7- 15 t/ha ash & $56 \mathrm{~d}$ & $26 \mathrm{c}$ & $20.11 \mathrm{~d}$ & $2.90 \mathrm{e}$ & $120.0 \mathrm{c}$ \\
T8-(2.5+2.5) t/ha compost + ash & $54 \mathrm{e}$ & $27 \mathrm{~cd}$ & $19.26 \mathrm{~cd}$ & $2.28 \mathrm{c}$ & $172.4 \mathrm{e}$ \\
T9-(5.5+5.5) t/ha compost + ash & $59 \mathrm{c}$ & $30 \mathrm{e}$ & $19.36 \mathrm{~cd}$ & $2.91 \mathrm{e}$ & $198.0 \mathrm{~g}$ \\
T10- $(7.5+7.5) \mathrm{t} /$ ha compost+ash & $69 \mathrm{a}$ & $34 \mathrm{f}$ & $23.56 \mathrm{e}$ & $3.26 \mathrm{~g}$ & $210.0 \mathrm{~h}$ \\
\hline
\end{tabular}

Mean values with the same letter (s) in a column do not differ significantly from each other at 5\% level by DMRT.

Dry weight of shoot and root

Dry weight of shoot of cherry tomato ranged from 13.56 $\mathrm{g} /$ plant recorded in control to $23.56 \mathrm{~g} /$ plant recoded in the treatment $\mathrm{T} 10$ receiving $(7.5+7.5) \quad \mathrm{t} / \mathrm{ha}$ compost $+\mathrm{ash}$ (Table I). Treatment T5 recorded statistically similar shoot dry weight but the effects of ash were higher over control. Application of compost/ash to the plots (single or in mixture) resulted significantly higher root dry weight compared to the plots not amended with compost/ash. This finding agrees with the results of Stoffella and Graetz (2000) (Table I).

Number of cluster per plant

Treatment $\mathrm{T} 10$ receiving $7.5 \mathrm{t}$ compost $+7.5 \mathrm{t}$ ash/ha recorded highest number of 17.43 cluster per plant (Table II). The effect of treatment $\mathrm{T} 9$ receiving $5.5 \mathrm{t}$ compost $+5.5 \mathrm{t}$ ash/ha was statistically similar as that of T10 in recording number of cluster/plant. However, the effects of treatments T9 and T10 were superior to the rest of the treatments. Treatments T6 receiving $10 \mathrm{t}$ ash/ha and $\mathrm{T} 7$ receiving $15 \mathrm{t} / \mathrm{ha}$ ash were statistically similar to the effect of $\mathrm{T} 8$ receiving $2.5 \mathrm{t}$ compost $+2.5 \mathrm{t}$ ash/ha but their effects were superior over control.

\section{Number of flower per plant}

The number of flower/plant was the highest (35.16) in the treatment $\mathrm{T} 10$ receiving $(7.5+7.5) \mathrm{t} /$ ha compost + ash (Table II). The effect of treatment $\mathrm{T} 9$ receiving $5.5 \mathrm{t}$ compost $+5.5 \mathrm{t}$ ash/ha and treatment T4 receiving 15t/ha compost was statistically similar number of flower/plant as that of T10. Treatments containing $5 \mathrm{t} / \mathrm{ha}$ compost/ash alone irrespectively of level used could not perform well.

Table II. Effects of plant residue compost and ash on flowering and fruiting characteristics of cherry tomato

\begin{tabular}{|c|c|c|c|c|}
\hline Treatment & $\begin{array}{c}\text { No of } \\
\text { cluster/plant }\end{array}$ & $\begin{array}{c}\text { No of } \\
\text { flower/plant }\end{array}$ & $\begin{array}{c}\text { No of } \\
\text { fruit/plant }\end{array}$ & $\begin{array}{l}\text { Fruit setting } \\
\text { rate }(\%)\end{array}$ \\
\hline T1- Control & $11.42 \mathrm{~d}$ & $21.26 \mathrm{~d}$ & $7.35 \mathrm{~d}$ & 34.57 \\
\hline $\mathrm{T} 2-5 \mathrm{t} / \mathrm{ha}$ compost & $12.77 \mathrm{c}$ & $21.86 \mathrm{~d}$ & $7.33 \mathrm{~d}$ & 33.53 \\
\hline T3 -10 t/ha compost & $12.33 \mathrm{~cd}$ & $25.46 \mathrm{~cd}$ & $9.16 \mathrm{bc}$ & 35.98 \\
\hline $\mathrm{T} 4-15 \mathrm{t} / \mathrm{ha}$ compost & $12.99 \mathrm{c}$ & $32.69 \mathrm{a}$ & $9.21 \mathrm{bc}$ & 28.17 \\
\hline T5- $5 \mathrm{t} / \mathrm{ha}$ ash & $11.43 \mathrm{~d}$ & $21.28 \mathrm{~d}$ & $8.35 \mathrm{~cd}$ & 39.24 \\
\hline T6 -10 t/ha ash & $14.93 \mathrm{~b}$ & $27.19 \mathrm{bc}$ & $9.34 \mathrm{bc}$ & 34.35 \\
\hline T7- $15 \mathrm{t} / \mathrm{ha}$ ash & $15.4 \mathrm{~b}$ & $28.12 \mathrm{bc}$ & $9.54 \mathrm{bc}$ & 33.93 \\
\hline $\mathrm{T} 8-(2.5+2.5) \mathrm{t} / \mathrm{ha}$ compost $+\mathrm{ash}$ & $15.73 \mathrm{~b}$ & $21.92 \mathrm{~d}$ & $8.76 \mathrm{bcd}$ & 39.96 \\
\hline T9- $(5.5+5.5) \mathrm{t} / \mathrm{ha}$ compost $+\mathrm{ash}$ & $17.23 \mathrm{a}$ & $31.82 \mathrm{ab}$ & $10.21 \mathrm{ab}$ & 32.09 \\
\hline $\mathrm{T} 10(7.5+7.5) \mathrm{t} / \mathrm{ha}$ compost $+\mathrm{ash}$ & $17.43 \mathrm{a}$ & $35.16 \mathrm{a}$ & $10.98 \mathrm{a}$ & 31.23 \\
\hline
\end{tabular}

Mean values with the same letter (s) in a column do not differ significantly from each other at $5 \%$ level by DMRT. 


\section{Number of fruits per plant}

Treatment $\mathrm{T} 10$ receiving $7.5 \mathrm{t}$ compost $+7.5 \mathrm{t}$ ash/ha recorded highest number of 10.98 fruits per plant (Table II). The effect of treatment $\mathrm{T} 9$ receiving $5.5 \mathrm{t}$ compost $+5.5 \mathrm{t}$ ash $/ \mathrm{ha}$ was statistically similar as that of T10 in recording number of fruits/plant. However, the effects of treatments T9 and T10 were superior to the rest of the treatments. Treatments T6 receiving $10 \mathrm{t}$ ash/ha and $\mathrm{T} 7$ receiving $15 \mathrm{t} / \mathrm{ha}$ ash were statistically similar to the effect of T8 receiving $2.5 \mathrm{t}$ compost $+2.5 \mathrm{t}$ ash/ha but their effects were higher over control.

Fruit setting rate (\%)

The rate of fruit setting varied due to different treatments (Table II). The fruit setting rate ranged from 28.17 recorded in T4 receiving $15 \mathrm{t}$ compost/ha to $39.96 \mathrm{recorded}$ in the treatment $\mathrm{T} 8$ receiving $2.5 \mathrm{t}$ compost $+2.5 \mathrm{t}$ ash/ha. Different rates of compost along with nitrogen affected the rate of fruit setting was reported (Solaiman and Rabbani, 2007).

\section{Fruit yield per plant}

Treatment $\mathrm{T} 10$ receiving $7.5 \mathrm{t}$ compost $+7.5 \mathrm{t}$ ash/ha recorded the highest fruit yield of $210.0 \mathrm{~g} / \mathrm{plant}$ (Table I and III). Treatment $\mathrm{T} 5$ recorded statistically similar fruit yield/plant over control. Application of compost/ash to all plots (single or in mixture) resulted significantly higher fruit yield/plant compared to the plots not amended with compost/ash. Okur et al., (1999) found that total fruit yield was the highest (3.9 $\mathrm{kg} / \mathrm{m}^{2}$ ) in the clay soil amended with $15 \mathrm{t}$ compost/ha. Similar results were also observed by Solaiman and Rabbani, (2007).
Fruit yield per ha

The trend of increase in fruit yield/ha was similar as that of fruit yield/plant. As of fruit yield/plant the highest fruit yield/ha was recorded in the treatment $\mathrm{T} 10$ receiving $7.5 \mathrm{t}$ compost $+7.5 \mathrm{t}$ ash/ha (Table III). Treatment $\mathrm{T} 5$ recorded statistically similar fruit yield/ha over control. All the treatments except $\mathrm{T} 5$ recorded significantly higher fruit yield/ha over control. This finding is supported by Pribetic et al., (2000). They obtained the highest tomato yield of $62.3 \mathrm{t} / \mathrm{ha}$ by the application of compost and mineral fertilizer. The compost was applied alone or in a mixture with ash. Cherry tomato yields were higher with the mixture than with compost/ash alone. Treatments T2, T3, T4, T5, T6, T7, T8, T9 and $\mathrm{T} 10$ recorded 52.67, 64.12, 79.39, 0.95, 3.82, 14.50, $64.50,88.93$ and $100.38 \%$ increase of fruit yield over control, respectively (Table III). The dry matter yield of cabbage was significantly increased by $40 \%$ due to the application of $500 \mathrm{~g}$ compost than the control as reported (Chamon et al. 2005, 2006). Cattle manure gave the highest dry matter yield of maize, while sewage sludge resulted in the lowest (Ismail et al. 1996).

\section{Economic performance}

The highest gross return (Tk. 2,10,000/ha) was obtained from the treatment $\mathrm{T} 10$ receiving $7.5 \mathrm{t}$ compost $+7.5 \mathrm{t}$ ash/ha, which was followed by treatment T9 (Tk. 1,98,000/ha) receiving $5.5 \mathrm{t}$ compost $+5.5 \mathrm{t}$ ash/ha and treatment T8 (Tk. $1,72,400 / \mathrm{ha}$ ) receiving $2.5 \mathrm{t}$ compost $+2.5 \mathrm{t}$ ash/ha (Table IV). All the treatments recorded higher gross return over control. Similar trend was also observed in case of net return. The highest total variable cost was recorded in the treatment

Table III. Effects of plant residue compost and ash on yield of cherry tomato

\begin{tabular}{lcccc}
\hline Treatment & $\begin{array}{c}\text { Tomato yield } \\
(\mathrm{FW}) \mathrm{g} / \mathrm{plant}\end{array}$ & $\begin{array}{c}\text { Tomato yield } \\
(\mathrm{FW}) \mathrm{kg} / \mathrm{plot}\end{array}$ & $\begin{array}{c}\text { Tomato yield } \\
(\mathrm{FW}) \mathrm{t} / \mathrm{ha}\end{array}$ & $\begin{array}{c}\text { Yield increase } \\
\text { over control (\%) }\end{array}$ \\
\hline T1- Control & $104.80 \mathrm{a}$ & 0.524 & $5.24 \mathrm{a}$ & \\
T2- $5 \mathrm{t} / \mathrm{ha}$ compost & $160.00 \mathrm{~d}$ & 0.800 & $8.00 \mathrm{~d}$ & 52.67 \\
T3 -10 t/ha compost & $172.00 \mathrm{e}$ & 0.860 & $8.60 \mathrm{e}$ & 64.12 \\
T4 -15 t/ha compost & $188.00 \mathrm{f}$ & 0.940 & $9.40 \mathrm{f}$ & 79.39 \\
T5- $5 \mathrm{t} / \mathrm{ha}$ ash & $105.80 \mathrm{a}$ & 0.529 & $5.29 \mathrm{a}$ & 0.95 \\
T6 -10 t/ha ash & $108.80 \mathrm{~b}$ & 0.544 & $5.44 \mathrm{~b}$ & 3.82 \\
T7- $15 \mathrm{t} / \mathrm{ha}$ ash & $120.00 \mathrm{c}$ & 0.600 & $6.00 \mathrm{c}$ & 14.50 \\
T8- $(2.5+2.5) \mathrm{t} / \mathrm{ha}$ compost + ash & $172.40 \mathrm{e}$ & 0.862 & $8.62 \mathrm{e}$ & 64.50 \\
T9- $(5.5+5.5) \mathrm{t} / \mathrm{ha}$ compost + ash & $198.00 \mathrm{~g}$ & 0.990 & $9.90 \mathrm{~g}$ & 88.93 \\
T10 (7.5+7.5) t/ha compost + ash & $210.00 \mathrm{~h}$ & 1.050 & $10.50 \mathrm{~h}$ & 100.38 \\
\hline
\end{tabular}

Mean values with the same letter (s) in a column do not differ significantly from each other at 5\% level by DMRT. 
Table IV. Economic performance of cherry tomato as affected by plant residue compost and ash

\begin{tabular}{lccccc}
\hline Treatment & $\begin{array}{c}\text { Yield (FW) } \\
\text { t/ha }\end{array}$ & $\begin{array}{c}\text { Gross return } \\
(\mathrm{Tk} / \mathrm{ha})\end{array}$ & $\begin{array}{c}\text { Total variable } \\
\text { cost (Tk/ha) }\end{array}$ & $\begin{array}{c}\text { Net Return } \\
(\mathrm{Tk} / \mathrm{ha})\end{array}$ & $\begin{array}{c}\text { Benefit cost } \\
\text { ratio (BCR) }\end{array}$ \\
\hline \multicolumn{1}{c}{1} & 2 & 3 & 4 & $5=(3-4)$ & $6=(3 / 4)$ \\
\hline T1- Control & 5.24 & 104800 & 54021 & 50779 & 1.94 \\
T2- 5 t/ha compost & 8.00 & 160000 & 58171 & 101829 & 2.75 \\
T3 -10 t/ha compost & 8.60 & 172000 & 62321 & 109679 & 2.76 \\
T4 -15 t/ha compost & 9.40 & 188000 & 66471 & 121529 & 2.83 \\
T5- 5 t/ha ash & 5.29 & 105800 & 56921 & 48879 & 1.86 \\
T6 -10 t/ha ash & 5.44 & 108800 & 59821 & 48979 & 1.82 \\
T7- $15 \mathrm{t} / \mathrm{ha}$ ash & 6.00 & 120000 & 62721 & 57279 & 1.91 \\
T8- $(2.5+2.5) \mathrm{t} / \mathrm{ha}$ compost + ash & 8.62 & 172400 & 57546 & 114854 & 3.00 \\
T9- $(5.5+5.5) \mathrm{t} / \mathrm{ha}$ compost + ash & 9.90 & 198000 & 61776 & 136224 & 3.21 \\
T10 $(7.5+7.5) \mathrm{t} / \mathrm{ha}$ compost + ash & 10.50 & 210000 & 64596 & 145404 & 3.25 \\
\hline
\end{tabular}

Compost $=0.75 \mathrm{Tk} / \mathrm{kg}, \mathrm{Ash}=0.50 \mathrm{Tk} / \mathrm{kg}$

Tomato price: $20 \mathrm{Tk} / \mathrm{kg}$

T4 receiving $15 t$ compost/ha, which was closely related with other treatments except control. The benefit cost ratio (BCR) was higher in T10 (3.25), which was closely followed by T9 (3.21) and T8 (3.00) (Table IV).

The beneficial effect of the addition of organic manures in soils on plant growth and soil structure was also reported (Bassuk, 1986). It is well known that organic matter is not only an aggregating agent, but also an improver of soil structure and stability ( Rubio et al., 1994).

The positive influence of organic substances on plant growth is a well known phenomenon, which is due to indirect effects of humic substances acting as suppliers and regulators of plant nutrients and direct effects of humic substances e.g. as respiratory catalysts (Rubio et al,. 1994).

\section{Conclusion}

The above results suggested that plant residue application at the rate of $(7.5+7.5) t / h a$ compost + ash appeared to be the best treatment, which gave maximum benefit to the farmer/cultivator. Compost significantly increased fresh matter production of tomato fruit yield compared to the control. Between compost and ash, performance of compost was better. Cherry tomato yields were higher with the mixture than with compost/ash alone.

\section{Acknowledgement}

The authors thank the Department of Soil, Water and Environment, University of Dhaka and Bangladesh Institute of Nuclear Agriculture (BINA), Mymensingh, Bangladesh, for providing facilities for experiment and analyses of the samples.

\section{References}

Andrew S (1994), The tomato in America: early history, culture and cookery. ISBN-978-1-57003-000-0.

BARC (1997), Fertilizer Recommendation Guide. Bangladesh Agricultural Research Council. Dhaka, Bangladesh.

Bassuk NL (1986), Reducing lead uptake in lettuce. Hort. Sci. 21(4): 993-995.

Cassman KG, Datta SK de, Olk DC, Alcantra J, Sason M, Desalsota J and Dizon M (1995), Yield decline and the nitrogen economy of long term experiment on continuous irrigated rice system in the tropics. In: R. Lal and BA Stewart (ed). Soil Management: Experimental basis for sustainability and environmental quality. Lewis Publisher, London, U. K. 181-222.

Chamon AS, Gerzabek MH, Mondol MN, Ullah SM, Rahman M and. Blum WEH (2005), Influence of soil amendments on heavy metal accumulation in crops on polluted soils of Bangladesh. Comm. Soil Sci. and Plant Analysis. 36: 907-924.

Chamon AS, Rahman MM, Mondol MN, Ali Z and SU Ahmed. (2006), Influence of plant residue compost and ash on growth, yield, mineral nutrition and quality of 
Chinese cabbage and tomato. Bangladesh J. Agric. And Environ. 2(2): 33-42.

Giardini L, Borin M, De. Nobili M and Fornasier F (1999), Effectti della fertilizzazione organica e dell avvicendamento delle colture sul contenuto di carbonio organico e sull attivita microbica del terreno. Riv. Agron. 33: 141-146.

Hue NV (1992), Correcting soil acidity of a highly weathered Ultisol with chicken manure and sewage sludge. Comm. Soil Sci.and Plant Analysis. 23: 241-264.

Ismail AS, Abdel S. and Abou N H (1996), Accumulation of heavy metals by plants as affected by application of organic wastes. Fourth National Congress on Pollution Control of Agricultural Environment. Egyptian J. Soil Sci. 36(1-4): 99-107.

Karim Z, Miah MMU and Razia S. (1994), Fertilizer in the national economy and sustainable environmental development. Asia Pacific J. Envir. Dev. 1: 48-67.

Okur B, Tuzel Y, Toksoz S, Anac D and Anac D (ed) and Martin PP (1999). Effects of compost material on yield and quality of glass house tomatoes grown in different textured soils. In: D. Anac (ed) Improved crop quality by nutrient management. Kluwer Academic Publishers, Dordrecht, Netherlands.219-222.

Pocknee S and Sumner ME (1997), Cation and nitrogen contents of organic matter determine its soil liming potential. Soil Sci. Soc. Am. J. 61: 86-92.

Pribetic D, Jurisic M and Vlaketic I (2000), Tomato yield depending on fertilization. Agronomski Glasnik. 62(56): 345-356.
Rubio MI, Escrig I, Martinez C, Lopez CF and Sanz A (1994), Cadmium and nickel accumulation in rice plants, effects on mineral nutrition and possible interaction of abscisic and gibberelic acid. Plant Growth Regul. 14: 151-157.

Saheed SM (1992), Land and Soil Resources Utilization Guide. In: Proceedings of the Inter Congress Conference of Commission IV: Improving soil management for intensive cropping in the tropics and sub tropics, Dhaka, Bangladesh.175-183.

Singh T and Dixit SK (1995), Extension of integrated plant nutrition systems. In: F.J. Dent and S. Gangwani (eds). Progress and problems in the integrated plant nutrition systems and farm level in Asia. Office for Asia and Pacific Food and Agriculture Organization of the United Nation, Maliwan Mansion, Phra Atil Road, Bangkok, Thailand. 71-86.

Solaiman ARM and Rabbani MG (2007), Effects of compost and nitrogen on growth and yield of tomato. J. Asiat. Soc. Bangladesh, Sci. 33(2): 175-183.

Stevenson FJ (1994), Humus Chemistry: Genesis, Composition, Reaction. Wiley Interscience, New York. 34-40.

Stoffella PJ and Graetz DA (2000), Utilization of sugarcane compost as a soil amendment in a tomato production system. Compost Science and Utilization. 8: 210-214.

Wong JWC, Ma KK, Fang KM and Cheung C (1999), Utilization of a manure compost for organic farming in Hong Kong. Bioresource Technology. 67(1): 43-46.

Received: 11 July 2012; Revised: 31July 2012; Accepted: 08 August 2012 . 